\title{
Makroselityksistä, vakauttajavaltioista ja kapitalismista
}

Teppo Eskelinen,YTT, dosentti, yliopistonlehtori, yhteiskuntatieteiden ja filosofian laitos, Jyväskylän yliopisto

Wolfgang Streeck avaa kirjassaan Ostettua aikaa (Streeck 2016) kapitalismin ja demokratian suhdetta. Tämä on olennaista ja ajankohtaista. Taloudellisten toimijoiden kyky suojautua demokraattiselta yhdenvertaisuusperiaatteelta on kapitalismin analyysin ydinkysymyksiä. On myös hyväksi, että marxilainen lähestymistapa lisää painoarvoaan yhteiskuntatieteellisessä keskustelussa. Kapitalististen yhteiskuntien muutosdynamiikkaa on vaikeaa selittää kokonaan ilman marxilaisia työkaluja. Järjestelmän selittäminen sen sisäänrakennettujen ristiriitojen kautta on huomattavasti hedelmällisempää kuin keinotekoiset tasapaino-oletukset.

Itse kirja ei kuitenkaan ole yhtä ongelmaton kuin sen tutkimuksellinen kehikko. Nostankin tässä esille kaksi kriittistä huomiota Streeckin ajattelusta. Huomioni koskevat "vakauttajavaltion" historiaa sekä kapitalismin normaalija poikkeustiloja.

\section{I}

Streeck kirjoittaa poliittista taloustiedettä makrososiologian otteella. Lähestymistavalle ominaista on pyrkimys erottaa poliittis-taloudellisen järjestelmien suuria kehityskulkuja satunnaisemman tapahtumien paljouden kohinasta. Haussa ovat siis keskipitkät tai pitkät systemaattiset kehityskulut. Streeck ei toki ole tässä yksin: jo Suomeksi on viime vuosina käännetty esimerkiksi Yanis Varoufakisin Maailmantalouden Minotauros (Varoufakis 2014) ja Immanuel Wallersteinin artikkeli osana usean kirjoittajan kokoomateosta 
(Wallerstein 2014).

Yksi tapa kuvata Streeckin hanketta onkin verrata hänen poliittisen taloustieteen analyysin tyyliään muihin vastaaviin suurten linjojen vetäjiin. Ilmeisenä erona on, että hän ei pyri ymmärtämään kulutuskysynnän lähteitä Varoufakisin tapaan, ja siinä mielessä argumentti on lähempänä uusklassista taloustiedettä. Hän ei myöskään pyri tekemään maailmanjärjestelmäteoriaa, jossa tunnistetaan hegemoni ja reuna-alueita, jotka joutuvat sopeuttamaan talousjärjestelmänsä hegemonin edun mukaisiksi.

Makrososiologinen ote on tärkeää ja välttämätöntä, kun yritetään ymmärtää suurempia historiallisia kehitystendenssejä. Talouden analyysi mahdollisimman yleisellä tasolla auttaa laittamaan kontekstiinsa yksittäisiä talouden tapahtumia ja näin selittää niitä maailmanhistoriallisia kehityskaaria. Samalla teoriamuoto on haastava ja ennen kaikkea jättää hyvin paljon valtaa kirjoittajalle. Kirjoittajan tulisi erottaa "aidot" makroilmiöt satunnaisemmasta taustakohinasta. Rajanveto on äärimmäisen vaikeaa.

Ei ole koskaan yksiselitteistä, minkälaiset asiat ovat riittävän merkittäviä ansaitakseen paikan makroteorian narratiivissa. Milloin esimerkiksi milloin yksittäiset vaalit, kriisi tai konkurssi tulisi mainita? Kirjoittajan erityinen vastuu näkyy juuri narratiiviin kelpuuttamisessa: jos jokin asia ei tule mainituksi, on luontevaa tulkita, ettei kirjoittaja pidä sitä suurena asiana. Tällaisessa kerronnassa kenties olennaisinta siis on, mitä ei käsitellä.

\section{II}

Streeckin pyrkimyksenä on kuvata spesifiä tilannetta ja toisaalta tiettyä valtiomuotoa. Esiin nostetaan "vakauttajavaltio" poliittisena muodostelmana ja toisaalta markkina- ja kansalaisuusperiaatteiden yhteentörmäys. On kuitenkin vaikeaa sanoa, miten universaali Streeckin analyysin kohde on. Hän selvästi esittää yleisiä havaintoja jonkinlaisesta "edistyneestä kapitalismista", mutta epäselväksi jää, millainen on edistyneen kapitalismin ja sen ulkopuolisen todellisuuden välinen dynamiikka.

Fokuksen pitäminen tiukasti Euroopassa (Yhdysvallat ja Japanikin sivuutetaan varsin kevyesti) osoittaa outoa välinpitämättömyyttä maailmanlaajuisia ilmiöitä kohtaan. "Vakauttajavaltiossa" ei nimittäin ole sinänsä mitään uutta. 
Se syntyi jo 1980-luvulla tai viimeistään 1990-luvulla Afrikassa ja latinalaisessa Amerikassa. Korkoshokki oli saattanut merkittävän osan globaalin Etelän valtioista velkaloukkuun, ja kansainväliset rahoituslaitokset reagoivat asiaan aggressiivisella talouden "sopeutusohjelmalla". Sen vaikutukset olivat kyseenalaisia, ja tuloksena oli huomattava talouden liberalisointi ja julkisten palveluiden alasajo.

Vakauttajavaltioista on siis paljonkin kokemusta: vakauttajavaltion politiikasta (rakennesopeutus), vakauttajavaltion tuottamista ristiriidoista ja myös vakauttajavaltion taloudellisista epäonnistumisista. Hanke ei tuottanut toivottuja tuloksia usein edes "markkinaväen" kriteereillä. Vakautettavista valtioista tuli pitkäksi aikaa kansainvälisten rahoituslaitosten holhokkeja. Ainoa asia, mikä on ollut viime vuosien Euroopassa uutta, on tämän mallin systemaattinen soveltaminen "kotona". Vakauttajavaltion politiikan saapuessa Eurooppaan, on monessa muussa paikassa jo käännytty kasvu- ja investointivetoisempaan politiikkaan.

Onko Streeckin argumentissa kyse siis kapitalismista ja demokratiasta yleisesti, vai jostain selvästi partikulaarimmasta ilmiöstä - Euroopasta, tai jopa EU:sta?

Sopii myös kysyä, miten rakenteellinen ilmiö vakauttajavaltio on, ja miten pitkälle poliittinen tahtotila. Vakauttajavaltio saapui globaaliin Etelään, koska IMF:llä ja Maailmanpankilla oli valtaa sanella poliittinen linja. Näiden instituutioiden linja ei myöskään ollut sattuma, vaan pitkällisten sisäisten ideologisten kamppailujen tulos. Ei ole selvää, että edes "markkinaväki" kannatti tuota linjaa yksiäänisesti. Jos kyse on linjasta, se on myös auki muutoksille. Aivan samalla tavalla Euroopassa oli poliittinen valinta, ryhdyttäisiinkö EteläEurooppaa "vakauttamaan" kuripolitiikalla vai omaksuttaisiinko investointivetoinen ja elvyttävä linja.

Streeck tuntuu myös olevan tiukasti kiinni sellaisessa marxilaisessa perinteessä, jossa kapitalismin kehitys nähdään universaaleja lainalaisuuksia noudattavana. Tällaisessa perinteessä on toki luontevaa tutkia edistyneitä kapitalismeja: muiden järjestelmien ristiriitojen voidaan olettaa kehittyvän tulevaisuudessa samansuuntaisesti. Kuitenkin viime vuosikymmenten opetus näyttäisi olevan juuri siinä, että tietyt uusliberalismin muodot ja tietyt valtiomuodot iskevät ensimmäisenä nimenomaan "periferiaan". Siksi vaikka toteutettu politiikka 
haluttaisiin ymmärtää tiukemmin rakenteelliseksi, "edistynyt" kapitalismi ei välttämättä ole edellä.

\section{III}

Streeckin kapitalismianalyysi nojaa pitkälti heijastumiin sodanjälkeisestä ristiriitojen kohtalokas kärjistyminen on Streeckin mukaan vältetty ainoastaan "ostamalla aikaa" ristiriitojen kärjistymisen estämiseksi. Välineitä tähän ovat olleet ennen kaikkea inflaatio, valtionvelka ja yksityinen velka.

Mutta miksi tarinan referenssipisteenä on sodanjälkeinen kapitalistinen kompromissi? Onko todella niin, että sodan jälkeen elettiin 20-30 vuotta kapitalistisen kompromissin "normaalitilassa" ja sen jälkeen on eletty "ostettua aikaa"? Toki sodanjälkeinen aika oli monilla tavoin onnistuneempaa kapitalismin hallinnointia kuin mitä sen jälkeen on nähty, mutta oliko sodanjälkeinen "normaali" todella niin vahva, että nykyaikaa määrittää nimenomaan tuon ratkaisun jälkeisyys? Vai onko kyse vain siitä, että Streeckille 1970luvun frankfurtilainen teoria on opiskeluaikojen teoreettinen koti, ja hän peilaa yhteiskunnallisia kehityskulkuja nimenomaan tuota teoriaa vasten lähinnä henkilöhistoriallisista syistä - kuten hän varsin rehellisesti tulee lähes todenneeksi?

Ilmeinen vaihtoehto olisi sanoa, että mitään kapitalismin "normaalia" ei ole koskaan ollutkaan. Kapitalismi on epävakaa järjestelmä, jota pitää jatkuvasti vakauttaa monenlaisin keinoin, ettei se romahtaisi. Se on lisäksi aina potentiaalisessa legitimaatiokriisissä. Siksi viimeiset vuosikymmenet eivät ole olleet "ajan ostamista", vaan ainoastaan huonompaa politiikkaa järjestelmän vakauttamiseksi, hallinnoimiseksi ja legitimoimiseksi.

Kysymys ei ole pelkästään teoreettinen. Puhe "ostetusta ajasta" uusintaa narratiivia, jonka mukaan ekspansiivinen finanssipolitiikka ja ylipäänsä kysyntää lisäävät toimet ovat "lykättyä verotusta". Kuitenkin "ostetuksi ajaksi" kutsutut välineet ovat usein nimenomaan osa hyvien järjestelmän vakauttamisen välineiden pakettia. Huonompien poliittisten välineiden ystävät sen sijaan iloisesti toistelevat tarinaa valtiontalouden välttämättömästä tasapainosta - ja puhe "ajan ostamisesta" sopii tähän oikein hyvin. 
Olisikin tärkeää erottaa selvemmin, minkälaiset asiat vaikuttavat uhkaavat demokratiaa. Streeck ei tee erityistä eroa institutionaalisten uhkien ja ideologisten uhkien välillä. Demokratiaa voidaan rajoittaa järjestämällä formaalit hallinnointiproseduurit antidemokraattisella tavalla, tai pyrkimällä yleistämään jokin demokratiaa rajoittava uskomus. Voi olla, että nykyisen politiikan välineillä olisi paljon nykyistä enemmän tosiasiallista toimintatilaa, mutta osa vaihtoehdoista on leimattu "populistisiksi" tai "vastuuttomiksi".

Rationaalisen hallinnoinnin ja demokratian määrittely on jatkuvaa kulttuurista kamppailua, ja soisin Streeckin kysyvän itseltään, missä määrin hänen argumentaationsa on demokraattista mielikuvitusta kaventavaa performatiivista yhteiskuntatiedettä.

\section{IV}

Kapitalismin ilmenemismuodot ja hallinnointijärjestelmät toki myös muuttuu, mutta voidaan olla montaa mieltä siitä, mikä näiden muutosten ydin on ollut. Streeckin mukaan valta on siirtynyt "markkinaväelle", mikä on varmasti paikkansapitävä ajatus sikäli, kun tarkoitetaan yleisempää talouden sfäärin kulttuurista laajenemista, yhteiskunnallisen vallan kasvua ja taloushallinnan priorisoitumista. Kuitenkin Streeck puhuu "markkinaväestä" monessa yhteydessä viitaten ainoastaan valtion velkakirjojen ostajiin.

"Markkinaväki" vaikuttaisi kuitenkin olevan kategoriana suurempi. 1970-luvulta alkaneista muutoksista tulisi huomioida ensinnäkin suuryritysten huomattava kasvu ja muuttuminen monikansallisiksi hallinnointijärjestelmiksi. Suuryritysten roolissa on korostunut - tuotannon kustannuksella - alihankinnan, logistiikan ja riskien hallinnointi, kirjanpito ja verojen optimointi sekä kulttuuristen mielikuvien tuotanto. Yritysten ja valtioiden välinen poliittinen neuvottelu on siis laajempi kysymys kuin kysymys valtion rahoituksesta.

Toiseksi olisi huomioitava yleinen finanssoituminen. Finanssoituminen ei tarkoita ainoastaan pankkien vallan kasvua, vaan myös muiden toimintojen muodonmuutosta. Finanssitalouden prioriteetit ja osittain myös toiminnot ovat tulleet osaksi tuotannollisten firmojen toimintaa, mikä näkyy erityisesti lyhytjänteisyydessä, mielikuvien keskeisyydessä sekä tuotannollisten yritysten 
halussa luoda rahoitustoimintoja osaksi toimintaansa. Lisäksi sosiaaliturvajärjestelmät ovat finanssoituneet "markkinaehtoisten" ratkaisujen yleistymisen myötä.

Kolmanneksi pitäisi mainita kauppasopimukset, jotka nousevat jatkuvasti esiin poliittisina välineinä demokratian kaventamiseksi. Tämä ei liity suoraan rahoittajien valtaan, vaan pikemmin investoijien konservatiivisuuteen: kun riskien hallinnointi korostuu suuryritysten toiminnoissa, niiden intressinä on varmistaa tietyn juridis-hallinnollisen kehikon pysyvyys. Joustajana on tietysti demokraattinen päätöksenteko, jonka liikkumatilaa tällainen lukitseminen tietysti rajoittaa.

On tietysti osittain turhan ankaraa kritisoida yhtä kirjaa siitä, ettei siihen mahdu kaikkea. Mutta jos halutaan muodostaa kuva siitä "markkinaväestä", joka tänä päivänä käy kamppailua demokratiaa vastaan, puhuminen valtioiden velkakirjojen ostajista on turhan kapeaa. Itse asiassa rahoituksen hallinta voi sopivissa institutionaalisissa puitteissa osoittautua valtioille paljon helpommaksi kuin muut taloudelliset ja taloushallinnolliset esteet.

\section{Lähteet}

Streeck, Wolfgang (2016) Ostettua aikaa. Demokraattisen kapitalismin lykätty kriisi. [Gekaufte Zeit]. Kääntänyt Mari Kukkonen. Vastapaino: Tampere. Varoufakis, Yanis (2014) Maailmantalouden minotauros. Vastapaino: Tampere. Wallerstein, Immanuel (2014) Rakenteellinen kriisi, eli miksi kapitalistit ehkä lakkaavat kokemasta kapitalismin palkitsevaksi? Kirjassa Immanuel Wallerstein, Randall Collins, Michael Mann, Georgi Derluguian \& Craig Calhoun: Onko kapitalismilla tulevaisuutta? Vastapaino: Tampere. 